\title{
Environmental determinants of latitudinal size-trends in cephalopods
}

\author{
Rui Rosa $^{1, *}$, Liliana Gonzalez ${ }^{2}$, Heidi M. Dierssen ${ }^{3}$, Brad A. Seibel ${ }^{4}$ \\ ${ }^{1}$ Laboratório Marítimo da Guia, Centro de Oceanografia, Faculdade de Ciências da Universidade de Lisboa, \\ Av. Nossa Senhora do Cabo, 939, 2750-374 Cascais, Portugal \\ ${ }^{2}$ Department of Computer Science and Statistics, University of Rhode Island, 9 Greenhouse Road, Kingston, \\ Rhode Island 02881, USA \\ ${ }^{3}$ Department of Marine Sciences, University of Connecticut, 1080 Shennecossett Road, Groton, Connecticut 06340-6048, USA \\ ${ }^{4}$ Department of Biological Sciences, University of Rhode Island, 100 Flagg Road, Kingston, Rhode Island 02881, USA
}

\begin{abstract}
Understanding patterns of body size variation is a fundamental goal in ecology, but although well studied in the terrestrial biota, little is known about broad-scale latitudinal trends of body size in marine fauna and much less about the factors that drive them. We conducted a comprehensive survey of interspecific body size patterns in coastal cephalopod mollusks, covering both hemispheres in the western and eastern Atlantic. We investigated the relationship between body size and thermal energy, resource and habitat availability and depth ranges. Both latitude and depth range had a significant effect on maximum body size in each of the major cephalopod groups (cuttlefishes, squids and octopuses). We observed significant negative associations between sea surface temperature (SST) and body size. No consistent relationships between body size and either net primary productivity (NPP), habitat extent (shelf area) or environmental variation (range of SST and NPP) were found. Thus, temperature seemed to play the most important role in structuring the distribution of cephalopod body size along the continental shelves of the Atlantic Ocean, and resource availability, seasonality or competition only played a limited role in determining latitudinal body size patterns.
\end{abstract}

KEY WORDS: Body size - Ectotherms - Cephalopods - Thermal energy · Resource availability · Latitude $\cdot$ Temperature-size rule

Resale or republication not permitted without written consent of the publisher

\section{INTRODUCTION}

Animal body size has an important influence on many physiological and ecological traits (Atkinson \& Hirst 2007, Seibel 2007, Rosa et al. 2009), community growth and abundance (Blackburn \& Gaston 1999, White et al. 2007) and ecosystem-scale energy flux and storage (Peters 1986). As a result, considerable effort has been devoted to the study of spatial patterns in body size, especially across large environmental gradients, to understand the organization of ecological communities. Bergmann (1847) was the first to propose a biogeographic 'rule' stating that smaller endotherms should, in general, abound in warmer areas, while larger-bodied species would inhabit colder climates. Underlying this hypothesis was the idea that a reduced surface to volume ratio at larger sizes facilitates greater heat conservation, allowing a lower mass-specific metabolic rate, whereas larger ratios in smaller individuals facilitate heat loss.

In the same context, but for ectothermic animals, a 'temperature-size rule' was postulated (Atkinson 1994), which argues that at lower temperatures (higher latitudes), ectotherms generally exhibit lower growth rates and delayed maturation but also grow to a larger body size. At higher temperatures, they tend to grow faster and mature at smaller sizes, but their adult body size is reduced. Although both 
hypotheses suggest that ambient energy (temperature) is the best environmental explanatory variable for the latitudinal-size trends, both lack a convincing mechanistic explanation. The resource availability (primary productivity) hypothesis assumes that body mass must be maintained by a sufficient food supply and predicts greater body sizes in more productive areas (Rosenzweig 1968). However, it is worth noting that cephalopods are voracious carnivores with many different feeding strategies that enable them to feed opportunistically on a wide range of prey (Rosa et al. 2004), and their growth seems to be primarily limited by predation rather than food shortages (Wood \& O'Dor 2000).

Some also argue that species adopt smaller body sizes in more equatorial areas because of increased inter- and intra-specific competition for resources (McNab 1971, Ashton et al. 2000). Because the feeding, behavior and reproduction of neritic cuttlefish, octopuses and squids are closely associated with seabed characteristics, one may argue that the larger continental shelves near the poles (i.e. greater habitat availability) could affect cephalopod body size variation by reducing competition. Moreover, variation in oxygen availability has been suggested to explain polar gigantism (Chapelle \& Peck 1999) and size increase in the deep sea (McClain \& Rex 2001, but also see Spicer \& Gaston 1999 for a rebuttal of this idea). Seasonality (or fasting endurance) has also been advocated to explain latitudinal size clines in both endo- and ectotherms, with large-bodied species being favored in colder and more variable environments because they can store more energy reserves (namely fat) to enhance survival during seasonal shortages of resources (Lindsey 1966, Boyce 1979). In marine systems, some argue that coastal animals tend to be bigger than deeper living counterparts (see the 'size-structure hypothesis' by Thiel $1975,1979)$. Yet, the generality of this phenomenon is not convincing because body size has been reported to decrease, increase or show no association with depth (see reviews by Gage \& Tyler 1991, Rex \& Etter 1998).

Although body size has been well studied in terrestrial biota, large-scale marine surveys of body size have been conducted only for fish (Lindsey 1966, Macpherson \& Duarte 1994), amphipods (Poulin \& Hamilton 1995, Chapelle \& Peck 1999), gastropods (Frank 1975, Olabarria \& Thurston 2003) and bivalve mollusks (Roy \& Martien 2001). Only 2 of these studies have covered both hemispheres (Poulin \& Hamilton 1995, Chapelle \& Peck 1999). In fact, while bathymetric variations in body size have been fairly well documented (Rex \& Etter 1998, Rex et al. 1999, 2006, McClain \& Rex 2001, McClain 2004, McClain et al. 2006), very little is known about broad-scale latitudinal trends in body size in marine fauna, and much less about the factors that drive them.

Here, we provide a comprehensive survey of largescale interspecific body size patterns for cephalopod mollusks along the continental shelves on both sides of the Atlantic. Furthermore, we investigate the relationship between latitudinal size trends and sea surface temperature (SST, an indicator of energy availability), net primary productivity (NPP, an indicator of resource availability), SST and NPP range (a proxy of seasonality) and shelf area (habitat availability, as a surrogate for competition), with depth ranges taken into account.

\section{METHODS}

\section{Species data}

After the assemblage of a species diversity database of cephalopods in the continental shelves (Rosa et al. 2008a), here, we present the latitudinal ranges and body sizes of coastal cephalopod fauna, i.e. species that are associated with, but not restricted to, continental shelves and depths shallower than $200 \mathrm{~m}$ in the Atlantic Ocean (Fig. 1). The body size database was constructed based on a comprehensive search of primary literature (e.g. Voss et al. 1998, Jereb \& Roper 2005), regional faunal compilations (e.g. Rosa \& Sousa Reis 2004) and expedition reports. Furthermore, an additional search was carried out in several journals that publish papers on the taxonomy and biogeography of cephalopod species (see Appendix 1 for more details). To examine the relationship between body size and latitude, we divided the western and eastern Atlantic corridors into $5^{\circ}$ latitudinal bins. Existing information on cephalopod biogeography did not permit finer resolution. We used the geometric mean of maximum length as a measure of size (here as maximum mantle length, MML). Although it is not the most common measure used to define latitudinal size patterns, MML is the most common standard measure (and sometimes the only available) for cephalopod species. The body size variable for each of the assemblages in each of the latitudinal bins had maximum skewness of 2.18 on the eastern side and 1.89 on the western side. The geometric mean is a useful measure of center when the distribution of the log-transformed original variable is made more symmetrical (Dallal 2007), and because the geometric 

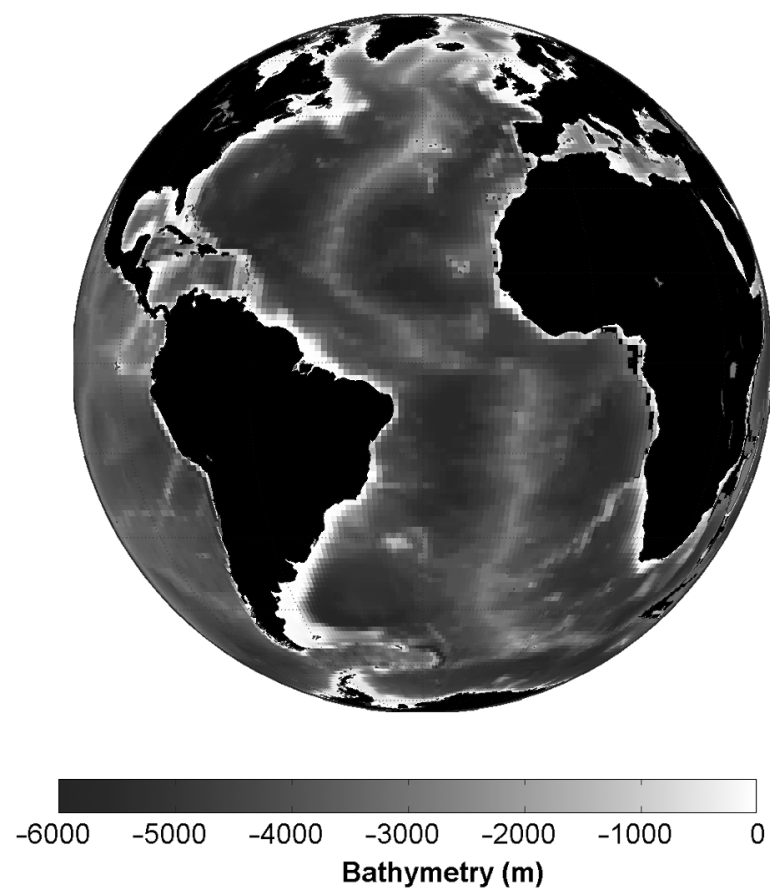

Fig. 1. Bathymetry in the Atlantic Ocean. White areas along the Atlantic coastal margins represent the continental shelves under study in the present investigation

mean is defined as the exponential of the average of the natural logs, it also has the advantage that the results are in the original scale of the data. Moreover, the geometric mean of body size is the metric most commonly used to investigate interspecific latitudinal patterns of body size, by providing some degree of standardization of shape differences among species (Hawkins \& Lawton 1995, Roy \& Martien 2001, Olabarria \& Thurston 2003). It is important to note that there are cases where the median of body size could be a better measure of center than the geometric mean (Meiri \& Thomas 2007). The bathymetric range for each species was also recorded.

\section{Effects of phylogeny}

Phylogenetic effects are known to influence spatial trends in body size (de Queiroz \& Ashton 2004). We tested these effects indirectly (in the absence of a well-resolved cladogram) by comparing the latitudinal patterns of body size at the class level (Cephalopoda) to those at the order level, namely Sepiida and Sepiolida (cuttlefishes), Teuthida (squids) and Octopodida (octopods). We also used the geometric mean of MML as a representative measure of body size within the orders.

\section{Environmental and spatial predictors}

Ocean NPP was estimated from the Vertically Generalized Production Model (Behrenfeld \& Falkowski 1997) with a temperature-dependent description of chlorophyll-specific photosynthetic efficiency applied to satellite-derived chlorophyll and sea surface temperature data from the MODIS Aqua sensor. Online Standard Products were downloaded as monthly, global $18 \mathrm{~km}$ gridded NPP data from November 2002 through October 2006 (OSU 2006). Because NPP follows a logarithmic distribution, the geometric mean was calculated for $5^{\circ}$ latitudinal increments along the western and eastern Atlantic shelves. Monthly SST was derived from MODIS Aqua imagery processed with the $4 \mu \mathrm{m}$ nighttime algorithm. For SST data, the arithmetic mean was calculated for each of the defined bins. We also determined the range of NPP and SST, a measure of variability (seasonality) in the data, calculated as the difference between maximum and minimum observations during the studied period. Habitat availability, i.e. continental shelf area extent, was determined using satellite-derived ocean bathymetry resampled at $1^{\circ}$ resolution (USDC 2006).

\section{Statistical analyses}

The statistical analyses were carried out in SAS (version 9.1.3) and run separately for the western and eastern margins and for the different cephalopod groups. Pearson's correlation coefficients were used to identify the relationships among all of the potential explanatory variables for latitudinal size patterns (Table 1). For subsequent analyses, because the data were binned in latitudinal bands, there was the concern of spatial dependency in the residuals; thus, lack of independency was accounted for when testing for associations between latitudinal size and other environmental variables. The spatial dependency in the data is in 1 dimension; hence, methods that apply to time series data can be used for statistical analysis (Cressie 1993, p. 200).

Simple and multiple regression analyses were used to test for associations among variables, and generalized Durbin-Watson statistics were used to check the order of autocorrelation present in the data (see Gujarati 1995). When autocorrelation was present, autoregressive models (AR models) were used to test for associations of variables. In the present study, the highest level of autocorrelation detected was of order 2 , and the largest number of variables included in a 
Table 1. Pearson correlation coefficients between sea surface temperature (SST), SST range, net primary productivity (NPP), NPP range, shelf area and depth range of Cephalopoda in western and eastern margins of the Atlantic Ocean. Significance levels are corrected for spatial autocorrelation. ${ }^{*} \mathrm{p}<0.05,{ }^{* *} \mathrm{p}<0.01, \#$ : excluding Eastern sepiolids

\begin{tabular}{|lccccc|}
\hline & SST & $\begin{array}{c}\text { SST } \\
\text { range }\end{array}$ & NPP & $\begin{array}{c}\text { NPP } \\
\text { range }\end{array}$ & $\begin{array}{c}\text { Shelf } \\
\text { area }\end{array}$ \\
\hline Western & & & & & \\
SST & 1 & & & & \\
SST range & -0.34 & 1 & & & \\
NPP & 0.23 & 0.28 & 1 & & \\
NPP range & -0.29 & $0.40^{*}$ & $0.72^{* *}$ & 1 & \\
Shelf area & $-0.66^{* *}$ & 0.18 & -0.35 & 0.13 & 1 \\
Depth range & $-0.97^{* *}$ & 0.37 & -0.23 & 0.27 & $0.68^{* *}$ \\
Eastern & & & & & \\
SST & 1 & & & & \\
SST range & -0.32 & 1 & & & \\
NPP & 0.34 & -0.36 & 1 & & \\
NPP range & 0.38 & -0.14 & $0.78^{* *}$ & 1 & \\
Shelf area & $-0.56^{* *}$ & $0.64^{* *}$ & $-0.61^{* *}$ & $-0.48^{*}$ & 1 \\
Depth range & -0.09 & $-0.45^{*}$ & -0.08 & -0.13 & -0.32 \\
Depth range (\#) & $-0.56^{* *}$ & -0.14 & -0.35 & -0.27 & -0.05 \\
\hline
\end{tabular}

model was 2 . Thus, a multiple regression model with 2 independent variables and second order autoregressive errors is defined as follows:

$$
\begin{gathered}
y_{l}=\beta_{0}+\beta_{1} x_{1 l}+\beta_{2} x_{2 l}+\varepsilon_{l} \\
\varepsilon_{l}=\rho_{1} \varepsilon_{l-1}+\rho_{2} \varepsilon_{l-2}+a_{l}
\end{gathered}
$$

where $y_{l}$ and $x_{i l}$ for $i=1,2$ are the observations of the response (size) and predictor variables (i.e. sea surface temperature, depth, etc.) respectively, at latitude $1, \varepsilon_{l}$ is the error term in the model at latitude $1, a_{l}$ is a normally and independently distributed $\left(0, \sigma_{a}^{2}\right)$ random variable, and $\rho_{i}$ with $i=1,2$ is the autocorrelation parameter or order 1 and 2 respectively. This model can easily be converted to a simple regression model by making $\beta_{2}=0$ and to have an autoregressive error of order 1 by setting $\rho_{2}=0$. If no autocorrelation is present in the model, then $\rho_{i}=0$ for $i=1,2$.

The AUTOREG procedure in SAS was used for the analyses, and the method of maximum likelihood was chosen over the Yule-Walker approach as the method of estimation because some of the data contained missing values (SAS 2008). Also, the estimates of standard errors calculated with the maximum likelihood method take into account the joint estimation of the regression parameters and AR components and may give more accurate standard errors than the Yule-Walker method. The goodness of fit statistics reported are the total- $\mathrm{R}^{2}$ and the Akaike's information criterion (AIC):

$$
\mathrm{R}_{\text {tot }}^{2}=1-[\mathrm{SSE} / \mathrm{SSTotal}]
$$

where SSTotal is defined as the corrected sum of squares total for the response variable, and SSE is the final error sum of squares. AIC is defined as follows:

$$
\mathrm{AIC}=-2 \ln (L)+2 k
$$

where $L$ is the value of the likelihood function evaluated at the parameter estimates, and $k$ is the number of estimated parameters.

\section{RESULTS}

\section{Latitude and body size}

The latitudinal distribution in mean body size of coastal cephalopod fauna in the western Atlantic (WA) and eastern Atlantic (EA) is shown in Fig. 2. The mean body size of squids (Order Teuthida) increased significantly towards the poles (Fig. 2C) in both the WA and EA ( $p<0.05$; Table 2). However, size-latitude relationships were more complex in the other cephalopod groups. While the mean body size of EA octopods followed a similar trend ( $\mathrm{p}<0.05$; Fig. 2D, Table 2), the size of WA octopods increased from the Patagonian shelf $\left(55^{\circ} \mathrm{S}\right)$ toward the equator but showed a steady increase toward the pole in the northern hemisphere. Sepiids, which became extinct in the WA, also revealed a clear trend of increasing size toward the pole in the northern hemisphere but not in the southern hemisphere (Fig. 2A). Sepiolids showed a marked difference in mean size from the Patagonian shelf to the other regions in the WA (Fig. 2B). In the EA, sepiolid body size was quite similar along the African coast until the Iberian/ Mediterranean latitudes, where it decreased due to the occurrence of several small Mediterranean endemic species (see historical explanations by Rosa et al. 2008a). Sepiolids were the only group to show, on average, smaller sizes in the EA than in the WA, and this had an enormous influence on the overall spatial-size pattern observed for the Class Cephalopoda in the EA (Fig. 2F, Table 2). The relationship between latitude and body size completely changed from a negative linear to a positive quadratic association with the inclusion (black circles in Fig. 2F) or exclusion (grey circles in Fig. 2F) of EA sepiolids. In the WA, the mean body size of Cephalopoda increased poleward ( $p<0.05$; Fig. 2E, Table 2), which was also clearly associated with an increase in size disparity (Fig. 3). It is worth noting that, in contrast to our previous study regarding spatial gradients of 

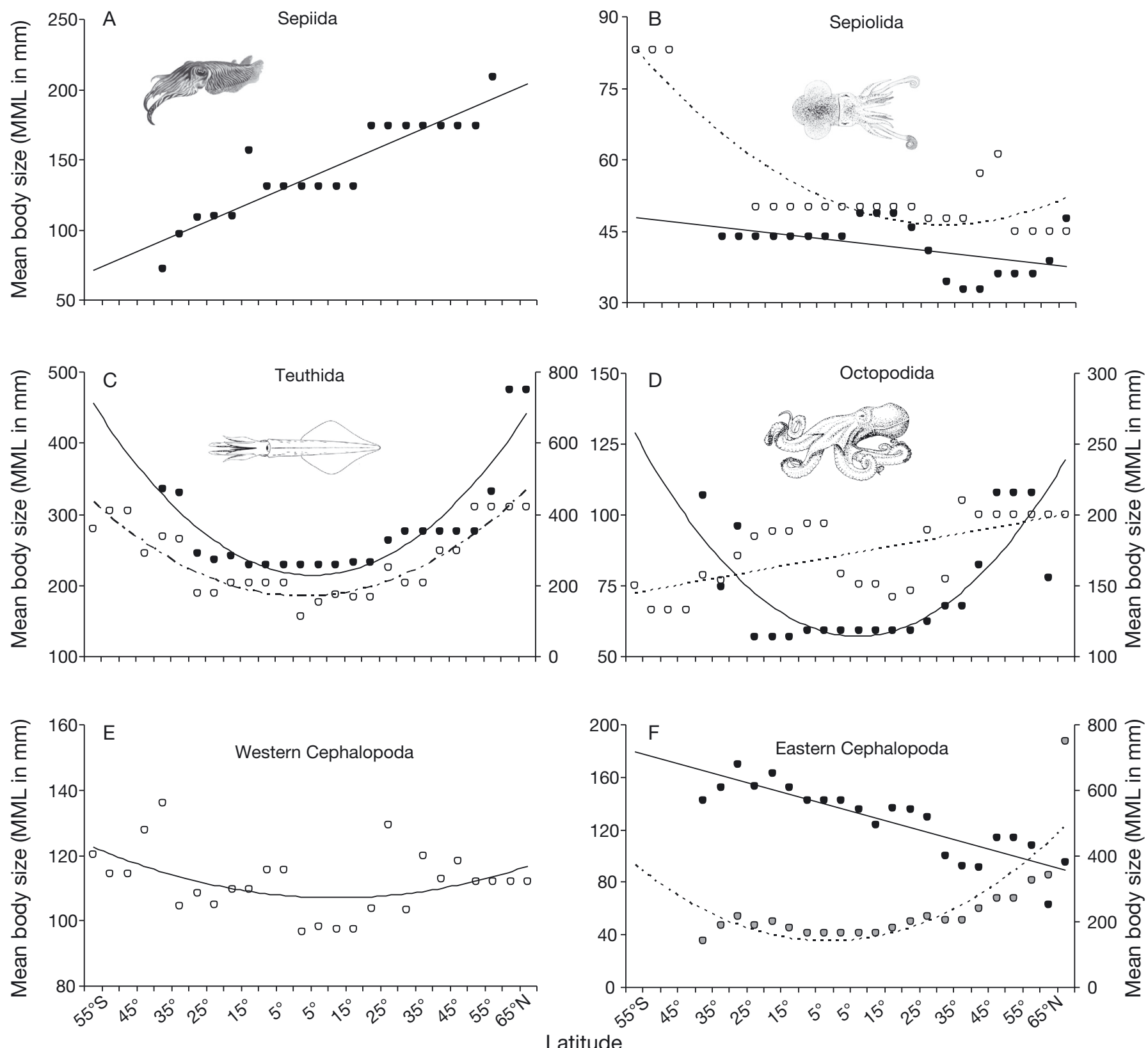

Fig. 2. Latitudinal variation in mean body size (maximum mantle length, MML in $\mathrm{mm}$ ) of coastal cephalopods in the western $(O$, left $y$-axis in panels C, D) and eastern (•, right $y$-axis in panels C, D) Atlantic. Grey circles in panel F represent the latitudinalsize relationship of the Class Cephalopoda in the eastern Atlantic after excluding the Order Sepiolida (right $y$-axis scale). Results from regression analysis, accounting for spatial autocorrelation, are shown in Table 2

cephalopod diversity (Rosa et al. 2008a), we did not include data from the Southern Ocean due to a lack of information on the maximum body size (mantle length) of coastal cephalopod fauna (namely octopods) on the Antarctic shelves. This fact limited the identification of spatial size patterns toward the South Pole, especially in EA, where the continental shelves end at $\sim 35^{\circ} \mathrm{S}$ (Figs. $2 \mathrm{~F} \& 3$ ).

\section{Depth range, environmental predictors, shelf area and body size}

Depth range played an important role in the observed body size patterns. In the WA, greater depth ranges were significantly associated with greater sizes in all group orders and at the class level (Table 3, Model 1). In the EA, in contrast, the associations were 


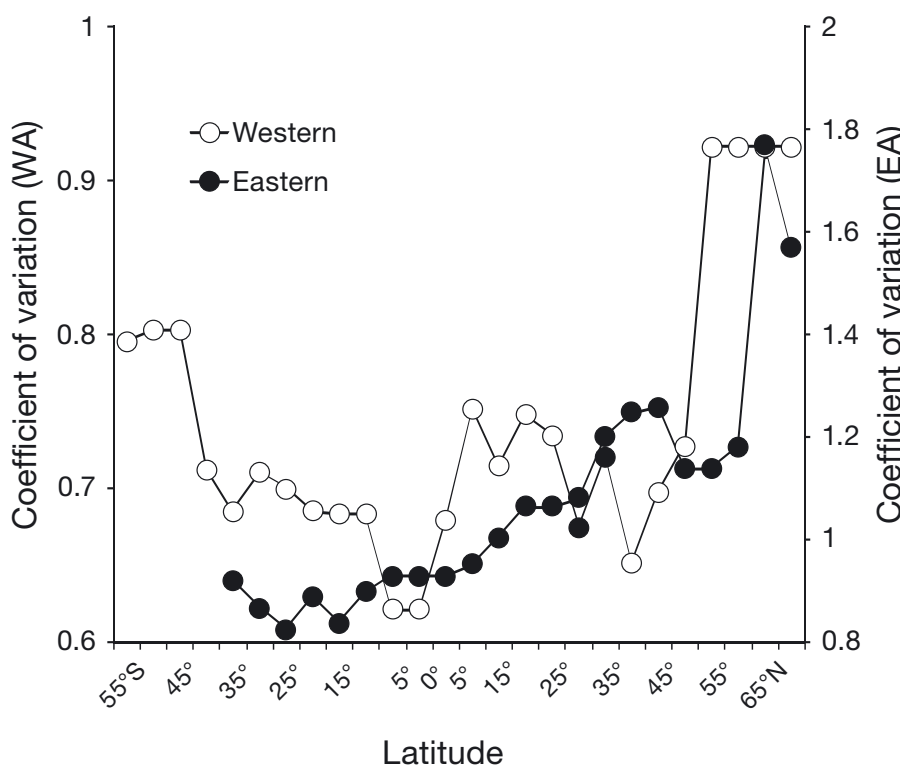

Fig. 3. Latitudinal trends in body size disparity (coefficients of variation) for Cephalopoda in the western (WA) and eastern (EA) Atlantic generally negative (Table 4, Model 1), with the exception of the Teuthida (squids), which showed a significant positive relationship ( $\mathrm{p}<0.01)$. In both Atlantic margins, the depth range of Cephalopoda was significantly and negatively associated with SST (Table 1).

SST ranged from $6^{\circ} \mathrm{C}$ at the polar latitudes to $>25^{\circ} \mathrm{C}$ at equatorial latitudes (Fig. 4A). For the WA, the temperature followed a near Gaussian distribution from polar to tropical latitudes. However, the patterns in the east were not nearly as continuous with latitude because of upwelling of cold water along the EA (e.g. the Benguela current off South Africa). Temperature was negatively associated with body size for almost all cephalopod orders and at the class level in both the WA and EA (Model 2 in Tables 3 \& 4). The strongest negative associations between size and temperature were observed in squids (WA p $<0.05$, EA p $<0.01$ ).

Mean NPP ranged from $<500 \mathrm{mg} \mathrm{C} \mathrm{m}^{-2} \mathrm{~d}^{-1}$ in the WA to $>4000 \mathrm{mg} \mathrm{C} \mathrm{m}^{-2} \mathrm{~d}^{-1}$ in the upwelling regions of the EA (Fig. 4B). The mean $( \pm \mathrm{SD})$ NPP was $784 \pm$ $317 \mathrm{mg} \mathrm{C} \mathrm{m}^{-2} \mathrm{~d}^{-1}$ for the WA and twice as high at

Table 2. Relationships between mean body size and latitude in the western and eastern Atlantic Ocean. Autocorrelation is taken into account in the estimates. Restricted maximum likelihood was used to estimate the parameters of each of the autoregressive models (AR). AIC: Akaike information criterion; +: not present in the western Atlantic; \#: excluding eastern Atlantic Sepiolida; -: no output

\begin{tabular}{|c|c|c|c|c|c|c|c|c|c|}
\hline & \multicolumn{5}{|c|}{ - Western Atlantic } & \multicolumn{4}{|c|}{ Eastern Atlantic } \\
\hline & Coefficient & $t$-ratio & $\mathrm{p}$ & Total $\mathrm{R}^{2}$ & $\mathrm{AIC}$ & Coefficient & $t$-ratio & $\mathrm{p}$ & Total $\mathrm{R}^{2}$ \\
\hline \multicolumn{10}{|l|}{ Sepiida } \\
\hline Latitude & + & + & + & + & + & 1.07 & 9.54 & $<0.0001$ & 0.84 \\
\hline Latitude $^{2}$ & + & + & + & & & - & - & - & \\
\hline $\operatorname{AR}(1)$ & + & + & + & & & - & - & - & \\
\hline \multicolumn{10}{|l|}{ Sepiolida } \\
\hline Latitude & -0.33 & -5.11 & $<0.0001$ & 0.86 & 136.92 & -0.02 & -0.21 & 0.8354 & 0.80 \\
\hline Latitude $^{2}$ & 0.00 & 2.51 & 0.0219 & & & - & - & - & \\
\hline $\mathrm{AR}(1)$ & 0.63 & 3.04 & 0.0071 & & & 1.44 & 5.72 & $<0.0001$ & \\
\hline $\mathrm{AR}(2)$ & - & - & - & & & -0.71 & -2.87 & 0.0107 & \\
\hline \multicolumn{10}{|l|}{ Theutida } \\
\hline Latitude & -0.88 & -6.95 & $<0.0001$ & 0.82 & 193.82 & -2.16 & -2.28 & 0.0348 & 0.86 \\
\hline Latitude $^{2}$ & 0.02 & 4.95 & $<0.0001$ & & & 0.13 & 6.06 & $<0.0001$ & \\
\hline $\mathrm{AR}(1)$ & - & - & - & & & -0.41 & -1.85 & 0.0804 & \\
\hline \multicolumn{10}{|c|}{ Octopodida } \\
\hline Latitude & 0.25 & 2.49 & 0.0206 & 0.47 & 209.05 & -0.66 & -2.39 & 0.0278 & 0.62 \\
\hline Latitude $^{2}$ & - & - & - & & & 0.03 & 5.01 & $<0.0001$ & \\
\hline $\mathrm{AR}(1)$ & 0.39 & 2.05 & 0.0516 & & & - & - & - & \\
\hline \multicolumn{10}{|l|}{ All } \\
\hline Latitude & -0.09 & -1.78 & 0.0877 & 0.20 & 192.12 & -0.73 & -7.88 & $<0.0001$ & 0.76 \\
\hline Latitude $^{2}$ & 0.00 & 2.20 & 0.0381 & & & - & - & - & \\
\hline $\mathrm{AR}(1)$ & - & - & - & & & - & - & - & \\
\hline \multicolumn{10}{|l|}{ All (\#) } \\
\hline Latitude & - & - & - & - & - & -0.17 & -0.21 & 0.8385 & 0.67 \\
\hline Latitude $^{2}$ & - & - & - & & & 0.07 & 4.06 & 0.0007 & \\
\hline $\mathrm{AR}(1)$ & - & - & - & & & - & - & - & \\
\hline
\end{tabular}


Table 3. Models assessing the importance of depth range, sea surface temperature (SST), net primary productivity (NPP), SST and NPP range and shelf area in predicting cephalopod body size variation in western Atlantic margins. For each variable, the $t$-ratios are included. Restricted maximum likelihood was used to estimate the parameters of each of the models. Models 1 to 5 evaluated the following: 1: size-depth clines; 2: the 'temperature-size rule'; 3: the 'resource availability' hypothesis; 4: the 'seasonality hypothesis'; 5: habitat availability as a surrogate for competition. ${ }^{*} p<0.05,{ }^{* *} p<0.01,{ }^{a}$ marginally significant $(p=0.05)$. AR: autoregressive

\begin{tabular}{|c|c|c|c|c|c|c|c|c|c|}
\hline Order & Model & $\begin{array}{l}\text { Depth } \\
\text { range }\end{array}$ & SST & NPP & $\begin{array}{c}\mathrm{SST} \\
\text { range }\end{array}$ & $\begin{array}{c}\text { NPP } \\
\text { range }\end{array}$ & $\begin{array}{c}\text { Shelf } \\
\text { area }\end{array}$ & $\begin{array}{c}\text { AR } \\
\text { order }\end{array}$ & $\begin{array}{c}\text { Total } \\
\mathrm{R}^{2}\end{array}$ \\
\hline Sepiolida & $\begin{array}{l}1 \\
2 \\
3 \\
4 \\
5\end{array}$ & $5.98^{* *}$ & -1.45 & -0.06 & -0.06 & 1.27 & -0.39 & $\begin{array}{l}1 \\
1 \\
1 \\
1 \\
1\end{array}$ & $\begin{array}{l}0.92 \\
0.83 \\
0.81 \\
0.83 \\
0.80\end{array}$ \\
\hline Theutida & $\begin{array}{l}1 \\
2 \\
3 \\
4 \\
5\end{array}$ & $2.01^{\mathrm{a}}$ & $-2.35^{*}$ & -0.03 & -0.36 & 0.76 & . & $\begin{array}{l}1 \\
1 \\
1 \\
1 \\
1\end{array}$ & $\begin{array}{l}0.69 \\
0.70 \\
0.62 \\
0.63 \\
0.63\end{array}$ \\
\hline Octopodida & $\begin{array}{l}1 \\
2 \\
3 \\
3 \\
4 \\
5\end{array}$ & $2.72^{*}$ & -1.14 & -0.50 & 1.49 & -0.92 & $2.19^{*}$ & $\begin{array}{l}1 \\
1 \\
1 \\
1 \\
1\end{array}$ & $\begin{array}{l}0.53 \\
0.41 \\
0.38 \\
0.42 \\
0.48\end{array}$ \\
\hline All & $\begin{array}{l}1 \\
2 \\
3 \\
4 \\
5\end{array}$ & $2.05^{\mathrm{a}}$ & $-2.20^{*}$ & 0.58 & 1.70 & $2.67^{*}$ & -0.03 & $\begin{array}{l}- \\
- \\
- \\
- \\
-\end{array}$ & $\begin{array}{l}0.15 \\
0.17 \\
0.01 \\
0.41 \\
0.00\end{array}$ \\
\hline
\end{tabular}

$1795 \pm 864 \mathrm{mg} \mathrm{C} \mathrm{m} \mathrm{m}^{-2} \mathrm{~d}^{-1}$ for the EA. No significant relationships were found between NPP and body size in either margin ( $p>0.05$, Model 3 in Tables 3 \& 4). With the exception of EA sepiolids, no significant relationships between size and seasonal variability (SST and NPP ranges) were also observed ( $p>0.05$, Model 4 in Tables 3 \& 4).

The continental shelf area was generally larger in the northern hemisphere than in southern hemisphere and increased towards the poles (Fig. 4C). The latitudinal variation of shelf area, here used as a proxy for habitat availability, was not relevant for the spatial size trends of all groups, except for octopods (WA p < 0.05 , EA p $=0.05$; Model 5 in Tables 3 $\& 4)$. The partly endemic EA sepiolids once again changed the relationship at the class level. With their exclusion, the association between shelf area and size of EA Cephalopoda turned from strongly significant $(\mathrm{p}<$ $0.0001)$ to non-significant ( $p>0.05$; Model 5 in Table 4).
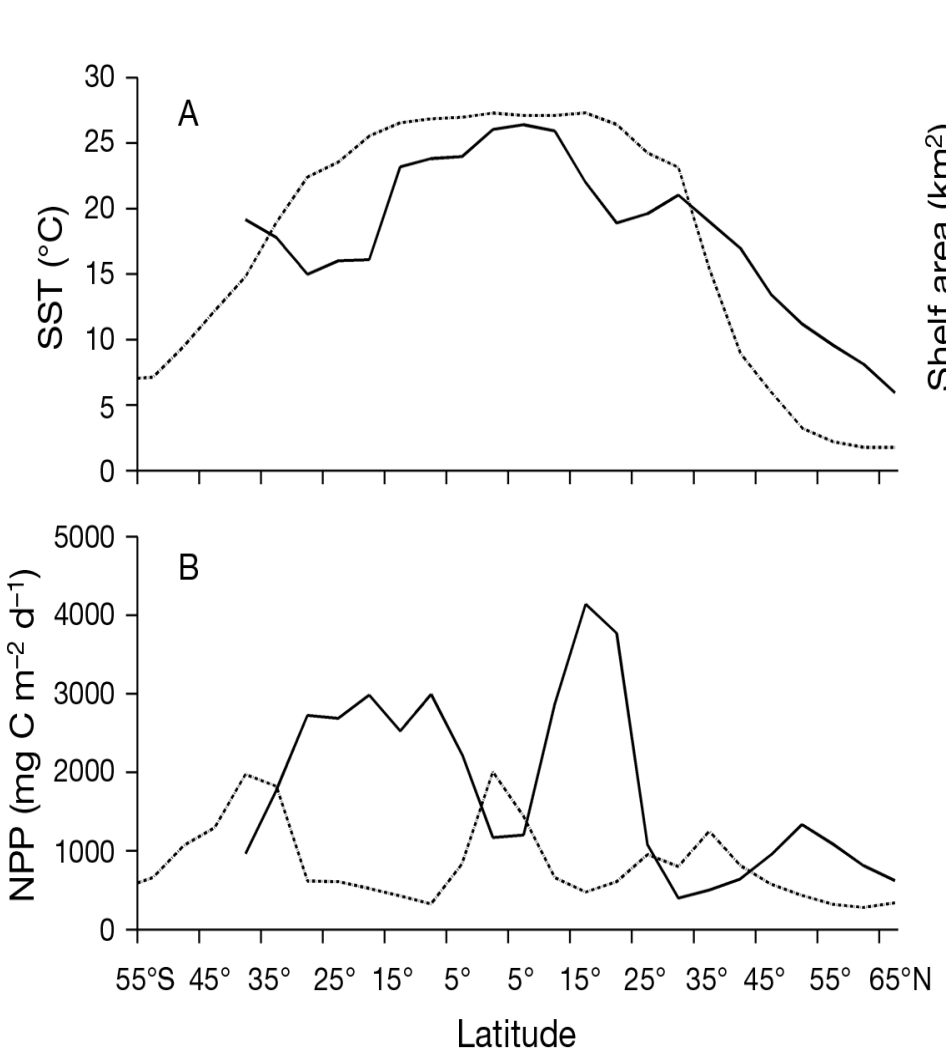

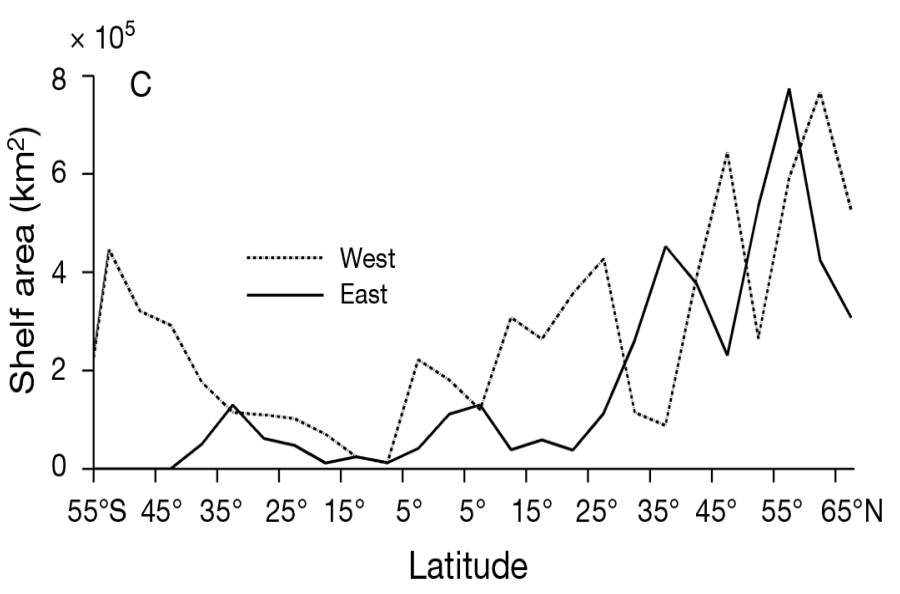

Fig. 4. Latitudinal trends of (A) sea surface temperature (SST), (B) net primary productivity (NPP), and (C) shelf area along the western and eastern Atlantic continental shelves 
Table 4. Models assessing the importance of depth range, sea surface temperature (SST), net primary productivity (NPP), SST and NPP range and shelf area in predicting cephalopod body size variation in eastern Atlantic margins. For each variable, the $t$-ratios are included. Restricted maximum likelihood was used to estimate the parameters of each of the models. For the purposes of Models 1 to 5, see Table 3. \#: excluding Sepiolida, ${ }^{*} \mathrm{p}<0.05,{ }^{* *} \mathrm{p}<0.01$, ${ }^{a}$ marginally significant $(\mathrm{p}=0.05)$. AR: autoregressive

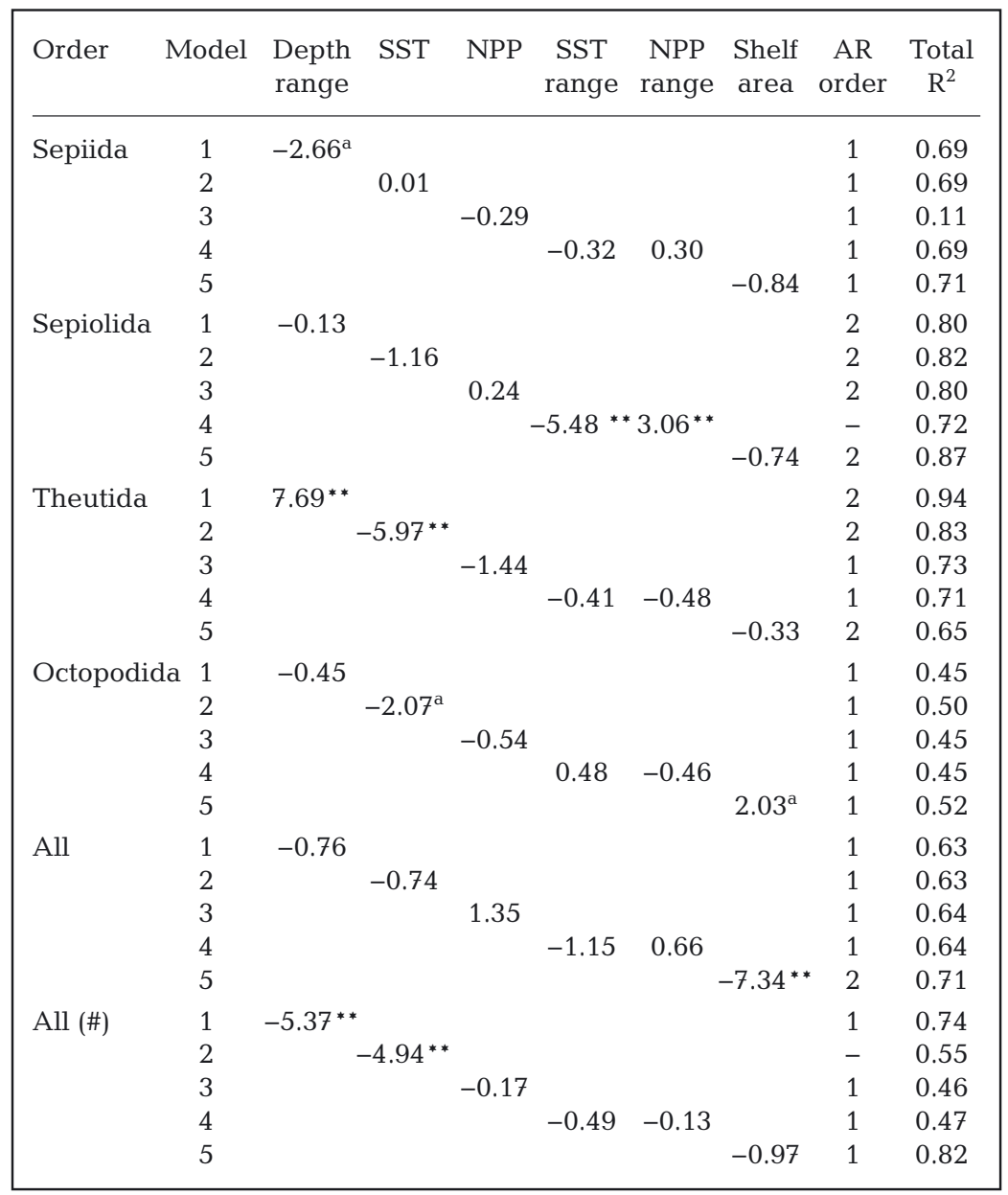

\section{DISCUSSION}

\section{Effect of latitude and depth on body size}

Previous studies have found a strong positive link between latitude and body size in shallow-living gastropods (Frank 1975), amphipods (Poulin \& Hamilton 1995) and fish (Macpherson \& Duarte 1994). However, latitude explained very little of the variance of body size in deep-sea gastropods (Olabarria \& Thurston 2003) or shallow-living bivalves (Roy \& Martien 2001). Here, we show that latitude has a significant effect on the mean body size of coastal cephalopods (Fig. 2, Table 2). A size increase toward the poles was supported at the class level (Cephalo- poda). At the order level, however, the increase in body size toward the poles was more robust in some groups (e.g. squids) than in others (e.g. sepiolids), and was inconsistent between hemispheres (e.g. for sepiids) and Atlantic margins (e.g. for octopods). These differences illustrate the greater complexity of patterns shown by ectotherms, as already seen in terrestrial systems (Hawkins \& Lawton 1995, Ashton \& Feldman 2003, Olalla-Tarraga \& Rodriguez 2007). Nonetheless, size increase toward the poles was supported at a higher taxonomic (class) level.

Depth range was significantly associated with body size in neritic cephalopods, underscoring the importance of accounting for this variable even in surveys restricted to coastal waters. However, opposite significant associations in the WA (positive) and EA (negative) were obtained (Tables 3 \& 4). Curiously, in addition to increasing their size, the members of the western neritic cephalopod fauna also increased their depth range with increasing latitude (Rosa et al. 2008a). Because the depth-size associations along Atlantic margins found here have opposite signs, no single hypothesis can be supported.

Though the present study only included coastal habitats, the majority of the neritic cephalopods are not strictly limited to the continental shelves. Some undertake seasonal migration toward the shelf break or to the upper slope (up to 500 to $700 \mathrm{~m}$ ) after breeding in more favorable onshore waters (e.g. coastal myopsid squids and incirrate octopuses Octopus and Eledone; Rosa \& Sousa Reis 2004). Additionally, the strong positive depth-size relationships (and latitudinal size clines) in squids in both margins also derives, in part, from the contribution of a larger-sized group (Suborder Oegopsina) that is periodically abundant in coastal habitats (e.g. genera Illex, Todaropsis and Todarodes; Boyle \& Rodhouse 2005). These squids are highly mobile predators with large bathymetric ranges that are well adapted to the seasonality of food resources and particularly abundant in highly productive regions at 
central (temperate) latitudes (Rosa et al. 2008b). Therefore, in addition to environmental forcing and physiological constraints (discussed below), the sizedepth-latitude relationships also reflect fundamental aspects of cephalopod feeding ecologies and life histories.

\section{Relating thermal energy and resource and habitat availability with body size}

Although the climate-based heat conservation hypothesis (see 'Introduction') may be plausible for endotherms (thermoregulators), it does not explain latitudinal-size relationships in marine ectotherms (thermoconformers), such as cephalopods. The prevalence of negative associations between temperature and body size in cephalopods (Tables 3 \& 4) seems to support the concept of the 'temperaturesize rule' (Atkinson 1994), i.e. at lower temperatures, cephalopods exhibit lower growth rates and delayed maturation but also grow to a larger body size. For instance, the giant octopus Enteroctopus dofleini lives at average temperatures of $10^{\circ} \mathrm{C}$ in the $\mathrm{NE}$ Pacific Ocean, achieves maturity at 10 to $15 \mathrm{~kg}$ ( 1020 d of age), grows to more than $5 \mathrm{~m}$ length $(>50 \mathrm{~kg}$ ) and has a life span of 4 to $5 \mathrm{yr}$ (Hartwick 1983). In contrast, the pigmy octopus Octopus joubini from WA tropical shallow waters (average lifetime temperatures of $25^{\circ} \mathrm{C}$ ) matures in $182 \mathrm{~d}$ (to a final weight of $30 \mathrm{~g}$ ) and attains a maximum total length of $15 \mathrm{~cm}$ (Hanlon 1983). Outside the neritic province, the 2 most striking examples of cold-associated gigantism are the 2 largest invertebrates of the oceans, namely the colossal Mesonychoteuthis hamiltoni and giant squids Architeuthis sp. Knowledge of the biology and ecology of those organisms is scarce (Pereira et al. 2005, Rosa \& Seibel 2010a). The first is known to be a reclusive inhabitant of the circumpolar Antarctic region that can weigh $>500 \mathrm{~kg}$ (Rosa \& Seibel 2010a), while the second is a widespread large oceanic predator (up to $16 \mathrm{~m}$ of total length) that, presumably, lives at mesopelagic depths (in temperatures of $\sim 10$ to $13^{\circ} \mathrm{C}$ ) and has a life span of several years (Landman et al. 2004). Although many small-sized counterexamples in polar/deep-sea habitats can be identified (e.g. small octopus Bathypolypus arcticus in North WA), the greater disparity of sizes in these cold environments seems unequivocal. This evidence is also supported by the general increase in size disparity (coefficients of variation) toward the poles shown in the present survey (Fig. 3). Other inter-specific studies also point out that larger size at maturity in cephalopods is a result of longer life spans (Van Heukelem 1976, Forsythe 1984, Wood \& O'Dor 2000) rather than faster growth rates (Calow 1987).

The 'temperature-size rule' was only tested in single populations of a single species (in a controlled environment), and therefore it assumes that all populations of a single species have the same reaction norm (i.e. no genetic differences between size at maturity and rearing temperature; see Belk \& Houston 2002, p. 807). Genetic divergence has been associated with latitudinal clines in body size (Partridge \& Coyne,1997, Gockel et al. 2001, de Jong \& Bochdanovits 2003); however, phenotypic plasticity seems to be a major contributor. Plasticity may be associated with thermal effects on growth and differentiation, namely on the size of cells (Partridge et al. 1994, Van Voorhies 1996), number of cells (James et al. 1997, Noach et al. 1997) or both (Zwaan et al. 2000) and at supra-cellular levels (e.g. organs; Nijhout 2003). These temperature-induced size changes can be interpreted as an integrated adaptive suite of acclimatory responses at all levels of organization to maintain aerobic scope and regulate oxygen supply (Pörtner 2002) as well as adjustments (Hochachka \& Somero 2002).

Some advocate that size decrease at lower (tropical) latitudes may be a strategy to mitigate oxygen limitation (i.e. small size may reduce maintenance costs that are otherwise elevated by temperature), which may also be exacerbated by the reduction in oxygen solubility with increasing temperature (Chapelle \& Peck 1999, Woods 1999). Although growth is initially faster at higher temperatures, it may slow down at a smaller size due to insufficient resource (oxygen) acquisition (Atkinson \& Sibly 1997). Reduced adult size at increased temperature and lower oxygen levels has also been observed in terrestrial ectotherms (Frazier et al. 2001). However, there is no evidence that the generally smaller size of tropical cephalopods is related to oxygen limitation. In fact, shallow-living cephalopods are not generally oxygen limited (especially octopuses and cuttlefish, but even squids) because they can regulate their oxygen consumption rate to $\sim 50 \%$ saturation. A good example is the jumbo squid Dosidicus gigas, a large jet-propelled predator (up to $50 \mathrm{~kg}$ of total weight) that lives in the eastern tropical Pacific, where temperature and oxygen are already found near the extremes in the oceans. It displays metabolic rates among the highest found in the oceans (Rosa \& Seibel 2008) and undergoes diel vertical migrations into the mesopelagic oxygen minimum zones. Inter- 
estingly, D. gigas circumvents oxygen limitation in the deep and hypoxic water (during the daytime) via metabolic suppression (Rosa \& Seibel 2010b).

Increased primary productivity has also been shown to have a positive effect on body size (Aava 2001) and is considered as a potential explanation of Bergmann's rule in terrestrial habitats (Rosenzweig 1968). At a given temperature, growth rates and size at maturity increase as food or resource availability increases (Atkinson \& Sibly 1997). In the present study, the differences in resource availability (as NPP) did not explain much of the variation of mean body size (Tables 3 \& 4). Seasonality (or fasting endurance) has also been advocated to explain latitudinal size clines (see 'Introduction'), but we did not find any evidence to support this hypothesis because environmental seasonality (as indicated by the range in SST and NPP) did not explain much of the variance of cephalopod size.

Because the feeding, behavior and reproduction of neritic cuttlefish, octopuses and squids are closely associated with seabed characteristics, larger continental shelves (greater habitat availability) could also explain body size variation by reducing competition. Reduced competition near the poles, where the continental shelves are wider, may also permit greater body sizes. This hypothesis seems to find some support among the order Octopodida, which curiously is the group more closely associated with the seabed. However, there is no direct evidence that competition for resources is a major driver of the growth and population dynamics of cephalopods.

Cephalopods are voracious carnivores with many different feeding strategies (including cannibalism) that enable them to feed opportunistically on a wide range of prey (e.g. Table 1 in Rosa et al. 2004), and, as already pointed out, many cephalopods also evolved migratory behaviors to exploit the seasonality of food resources. Thus, the growth of cephalopods in the wild seems to be primarily limited by predation rather than food shortages (Wood \& O'Dor 2000). Predation is more likely to limit the growth of cephalopods because consumption by marine mammals, sea birds and fish is widespread, with some feeding exclusively on cephalopods (e.g. some elasmobranchs; Boyle \& Rodhouse 2005). Yet, for the predation hypothesis to explain the present latitudinal size trends, the predation intensity for most cephalopod species must be positively correlated with latitude, which cannot be tested because relevant data are not available.

In conclusion, temperature seemed to play the most important role in structuring the distribution of cephalopod body size along the continental shelves of the Atlantic Ocean. Our findings show only a limited role of resource availability, seasonality or competition in determining latitudinal body size patterns.

Acknowledgements. The Portuguese Foundation for Science and Technology (FCT) supported this study through the project PTDC/BIA-BEC/103266/2008 to R.R. The authors also acknowledge Oregon State University, NASA and the Ocean Biology Processing Group (Code 614.2) at the Goddard Space Flight Center for the production and distribution of the ocean color data.

\section{LITERATURE CITED}

Aava B (2001) Primary productivity can affect mammalian body size frequency distributions. Oikos 93:205-213

> Ashton KG, Feldman CR (2003) Bergmann's rule in nonavian reptiles: turtles follow it, lizards and snakes reverse it. Evolution 57:1151-1163

> Ashton KG, Tracy MC, De Queiroz A (2000) Is Bergmann's rule valid for mammals? Am Nat 156:390-415

- Atkinson D (1994) Temperature and organism size-a biological law for ectotherms? Adv Ecol Res 25:1-58

Atkinson D, Hirst AG (2007) Life histories and body size. In: Hildrew A, Rafaelli D, Edmonds-Brown R (eds) Body size: the structure and function of aquatic ecosystems. Cambridge University Press, Cambridge, p 33-54

Atkinson D, Sibly RM (1997) Why are organisms usually bigger in colder environments? Making sense of a life history puzzle. Trends Ecol Evol 12:235-239

Behrenfeld MJ, Falkowski PG (1997) Photosynthetic rates derived from satellite-based chlorophyll concentration. Limnol Oceanogr 42:1-20

Belk MC, Houston DD (2002) Bergmann's rule in ectotherms: a test using freshwater fishes. Am Nat 160: 803-808

Bergmann C (1847) Ueber die Verhältnisse der Wärmeökonomie der Thiere zu ihrer Grösse (Concerning the relationship of heat conservation of animals to their size). Göttinger Studien 3:595-708

Blackburn TM, Gaston KJ (1999) The relationship between animal abundance and body size: a review of the mechanisms. Adv Ecol Res 28:181-210

Boyce MS (1979) Seasonality and patterns of natural selection for life histories. Am Nat 114:569-583

Boyle P, Rodhouse P (2005) Cephalopods: ecology and fisheries. Blackwell Publishing, Oxford

Calow P (1987) Fact and theory: an overview. In: Boyle PR (ed) Cephalopod life cycles: comparative reviews, Vol 2. Academic Press, London, p 351-366

Chapelle G, Peck LS (1999) Polar gigantism dictated by oxygen availability. Nature 399:114-115

Cressie NAC (1993) Statistics for spatial data, revised edn. Wiley, New York, NY

Dallal G (2007) The handbook of statistical practice. www. tufts.edu/ gdallal/LHSP.HTM

de Jong G, Bochdanovits Z (2003) Latitudinal clines in Drosophila melanogaster: body size, allozyme frequencies, inversion frequencies, and the insulin-signalling pathway. J Genet 82:207-223

de Queiroz A, Ashton KG (2004) The phylogeny of a specieslevel tendency: Species heritability and possible deep 
origins of Bergmann's rule in tetrapods. Evolution 58: 1674-1684

Forsythe JW (1984) Octopus joubini (Mollusca: Cephalopoda): a detailed study of growth through the full life cycle in a closed seawater system. J Zool 202:393-417

Frank PW (1975) Latitudinal variation in the life history features of the black turban snail Tegula funebralis (Prosobranchia: Trochidae). Mar Biol 31:181-192

Frazier MR, Woods HA, Harrison JF (2001) Interactive effects of rearing temperature and oxygen on the development of Drosophila melanogaster. Physiol Biochem Zool 74:641-650

Gage JD, Tyler PA (1991) Deep-sea biology: a natural history of organisms at the deep-sea floor. Cambridge University Press, Cambridge

Gockel J, Kennington WJ, Hoffmann A, Goldstein DB, Partridge L (2001) Nonclinality of molecular variation implicates selection in maintaining a morphological cline of Drosophila melanogaster. Genetics 158:319-323

Gujarati DN (1995) Basic econometrics, 3rd edn. McGrawHill, New York, NY

Hanlon RT (1983) Octopus joubini. In: Boyle PR (ed) Cephalopod life cycles: species accounts, Vol 1. Academic Press, London, p 293-310

Hartwick B (1983) Octopus dofleini. In: Boyle PR (ed) Cephalopod life cycles: species accounts, Vol 1. Academic Press, London, p 277-292

Hawkins BA, Lawton JH (1995) Latitudinal gradients in butterfly body sizes: is there a general pattern? Oecologia 102:31-33

Hochachka PW, Somero GN (2002) Biochemical adaptation: mechanisms and process in physiological evolution. Oxford University Press, Oxford

James AC, Azevedo RBR, Partridge L (1997) Genetic and environmental responses to temperature of Drosophila melanogaster from a latitudinal cline. Genetics 146: 881-890

Jereb P, Roper CFE (2005) Cephalopods of the world: an annotated and illustrated catalogue of cephalopod species known to date, No. 4, Vol 1. FAO species catalogue for fishery purposes, FAO, Rome

Landman NH, Coshran JK, Cerrato R, Mak J, Roper CFE, Lu CC (2004) Habitat and age of the giant squid (Architeuthis sanctipauli) inferred from isotopic analyses. Mar Biol 144:685-691

> Lindsey CC (1966) Body sizes of poikilotherm vertebrates at different latitudes. Evolution 20:456-465

> Macpherson E, Duarte CM (1994) Patterns in species richness, size, and latitudinal range of East Atlantic fishes. Ecography 17:242-248

> McClain CR (2004) Connecting species richness, abundance and body size in deep-sea gastropods. Glob Ecol Biogeogr 13:327-334

McClain CR, Rex MA (2001) The relationship between dissolved oxygen concentration and maximum size in deepsea turrid gastropods: an application of quantile regression. Mar Biol 139:681-685

> McClain CR, Boyer AG, Rosenberg G (2006) The island rule and the evolution of body size in the deep sea. J Biogeogr 33:1578-1584

> McNab TA (1971) On the ecological significance of Bergmann's rule. Ecology 52:845-854

Meiri S, Thomas GH (2007) The geography of body sizechallenges of the interspecific approach. Global Ecol Biogeogr 116:689-693
Nijhout HF (2003) The control of body size in insects. Dev Biol 161:1-9

Noach EJ, De Jong G, Scharloo W (1997) Phenotypic plasticity of wings in selection lines of Drosophila melanogaster. Heredity 79:1-9

Olabarria C, Thurston MH (2003) Latitudinal and bathymetric trends in body size of the deep-sea gastropod Troschelia berniciensis (King). Mar Biol 143:723-730

Olalla-Tarraga MA, Rodriguez MA (2007) Energy and interspecific body size patterns of amphibian faunas in Europe and North America: anurans follow Bergmann's rule, urodeles its converse. Glob Ecol Biogeogr 16: $606-617$

OSU (2006) Ocean productivity. Oregon State University, http://web.science.oregonstate.edu/ocean.productivity/

Partridge L, Coyne JA (1997) Bergmann's rule in ectotherms: is it adaptive? Evolution 51:632-635

> Partridge L, Barrie B, Fowler K, French V (1994) Evolution and development of body size and cell size in Drosophila melanogaster in response to temperature. Evolution 48:1269-1276

Pereira J, Rosa R, Moreno A, Henriques M, Sendao J, Borges TC (2005) First recorded specimen of the giant squid Architeuthis sp. in Portugal. J Mar Biol Assoc UK 85: 175-176

Peters RH (1986) The ecological implications of body size. Cambridge Studies in Ecology Series, Cambridge University Press, Cambridge

Pörtner HO (2002) Climate variation and the physiological basis of temperature dependent biogeography: systemic to molecular hierarchy of thermal tolerance in animals. Comp Biochem Physiol A 132:739-761

> Poulin R, Hamilton WJ (1995) Ecological determinants of body size and clutch size in amphipods: a comparative approach. Funct Ecol 9:364-370

Rex MA, Etter RJ (1998) Bathymetric patterns of body size: implications for deep-sea biodiversity. Deep-Sea Res II 45:103-127

Rex MA, Etter RJ, Clain AJ, Hill MS (1999) Bathymetric patterns of body size in deep-sea gastropods. Evolution 53: 1298-1301

Rex MA, Etter RJ, Morris JS, Crouse J and others (2006) Global bathymetric patterns of standing stock and body size in the deep-sea benthos. Mar Ecol Prog Ser 317:1-8

> Rosa R, Seibel BA (2008) Synergistic effects of climaterelated variables suggest future physiological impairment in a top oceanic predator. Proc Natl Acad Sci USA 105:20776-20780

Rosa R, Seibel BA (2010a) Slow pace of life of the Antarctic colossal squid. J Mar Biol Assoc UK 90:1375-1378

Rosa R, Seibel BA (2010b) Metabolic physiology of the Humboldt squid, Dosidicus gigas: implications for vertical migration in a pronounced oxygen minimum zone. Prog Oceanogr 86:72-80

Rosa R, Sousa Reis C (2004) Cephalopods of the Portuguese coast. Prémio do Mar- Rei D. Carlos. Câmara Municipal de Cascais, Cascais (in Portuguese)

Rosa R, Marques AM, Nunes ML, Bandarra N, Reis CS (2004) Spatial-temporal changes in dimethyl acetal (octadecanal) levels of Octopus vulgaris (Mollusca, Cephalopoda): relation to feeding ecology. Sci Mar 68: 227-236

Rosa R, Dierssen HM, Gonzalez L, Seibel BA (2008a) Ecological biogeography of cephalopod mollusks in the Atlantic Ocean: historical and contemporary causes of 
coastal diversity patterns. Glob Ecol Biogeogr 17: $600-610$

Rosa R, Dierssen HM, Gonzalez L, Seibel BA (2008b) Largescale diversity patterns of cephalopods in the Atlantic open ocean and deep-sea. Ecology 89:3449-3461

Rosa R, Trueblood L, Seibel BA (2009) Ecophysiological influence on scaling of aerobic and anaerobic metabolism of oceanic gonatid squids. Physiol Biochem Zool 82:419-429

Rosenzweig ML (1968) The strategy of body size in mammalian carnivores. Am Midl Nat 80:299-315

Roy K, Martien KK (2001) Latitudinal distribution of body size in north-eastern Pacific marine bivalves. J Biogeogr 28:485-493

SAS (2008) SAS/ETS, 9.1.3 user's guide. http://support.sas. com/documentation/onlinedoc/91pdf/index_913.html

Seibel BA (2007) On the depth and scale of metabolic rate variation: scaling of oxygen consumption rates and enzymatic activity in the Class Cephalopoda (Mollusca). J Exp Biol 210:1-11

Spicer JI, Gaston KJ (1999) Amphipod gigantism dictated by oxygen availability? Ecol Lett 2:397-401

Thiel H (1975) The size structure of the deep-sea benthos. Int Rev Gesamten Hydrobiol 60:576-606

Thiel H (1979) Structural aspects of the deep-sea benthos. Ambio Spec Rep 6:25-31

USDC (2006) 2-minute gridded global relief data
(ETOPO2v2), US Department of Commerce, National Oceanic and Atmospheric Administration, National Geophysical Data Center. www.ngdc.noaa.gov/mgg/fliers/ 06mgg01.html

Van Heukelem WF (1976) Growth, bioenergetics and lifespan of Octopus cyanea and Octopus maya. $\mathrm{PhD}$ thesis, University of Hawaii, Honolulu, HI

Van Voorhies WA (1996) Bergmann size clines: a simple explanation for their occurrence in ectotherms. Evolution 50:1259-1264

Voss NA, Vecchione M, Toll RB, Sweeney MJ (1998) Systematics and biogeography of cephalopods. Smithson Contrib Zool 586:1-276

White EP, Ernest SKM, Kerkhoff AJ, Enquist BJ (2007) Relationships between body size and abundance in ecology. Trends Ecol Evol 22:323-330

$>$ Wood JB, O'Dor RK (2000) Do larger cephalopods live longer? Effects of temperature and phylogeny on interspecific comparisons of age and size at maturity. Mar Biol 136:91-99

Woods HA (1999) Egg-mass size and cell size: effects of temperature on oxygen distribution. Am Zool 39:244-252

> Zwaan BJ, Azevedo RBR, James AC, van 't Lande J, Partridge L (2000) Cellular basis of wing size variation in Drosophila melanogaster: a comparison of latitudinal clines on two continents. Heredity 84:338-347

Appendix 1. Diversity (Fig. A1) and body size (maximum mantle length, MML, Tables A1 \& A2) in coastal cephalopods of the Atlantic Ocean

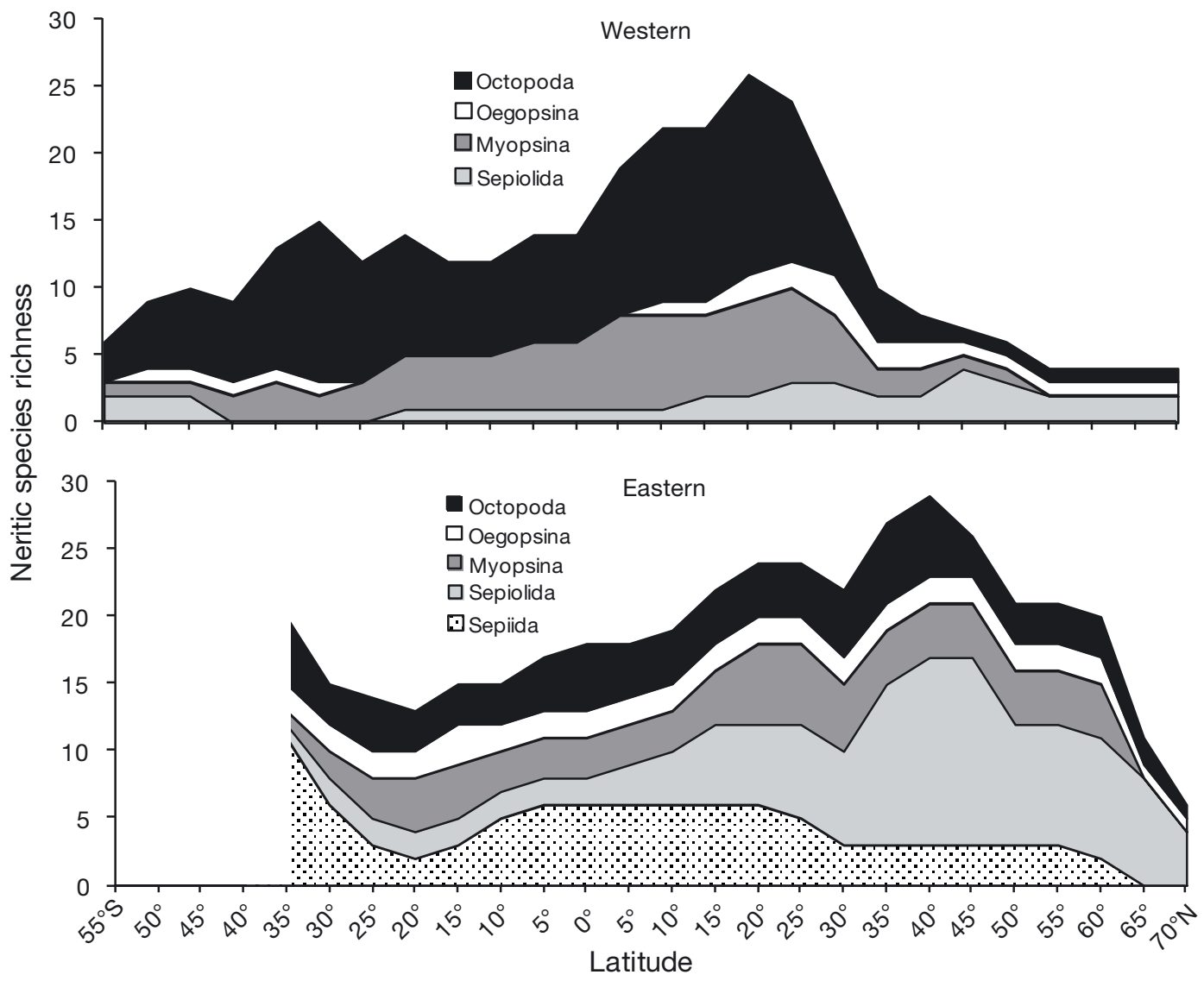

Fig. A1. Number of species per bin in both Atlantic margins (Western: from $55^{\circ} \mathrm{S}$ to $70^{\circ} \mathrm{N}$, Eastern: from $35^{\circ} \mathrm{S}$ to $70^{\circ} \mathrm{N}$ ). These diversity data were first presented and discussed by Rosa et al. (2008a) 
Table A1. Cephalopod sizes in the western Atlantic

\begin{tabular}{|c|c|}
\hline Species & $\begin{array}{c}\text { Maximum mantle } \\
\text { length (mm) }\end{array}$ \\
\hline Rossia palpebrosa & 45 \\
\hline Semirossia tenera & 50 \\
\hline Neorossia caroli & 83 \\
\hline Loligo gahi & 280 \\
\hline Loligo ocula & 130 \\
\hline Loligo pealeii & 200 \\
\hline Loligo plei & 350 \\
\hline Loligo roperi & 70 \\
\hline Loligo sanpaulensis & 160 \\
\hline Loligo surinamensis & 120 \\
\hline Lolliguncula (Lolliguncula) brevis & 120 \\
\hline Sepioteuthis sepioidea & 200 \\
\hline Illex coindetti & 370 \\
\hline Illex illecebrosus & 310 \\
\hline Illex argentines & 330 \\
\hline Illex oxygonius & 230 \\
\hline Enteroctopus megalocyathus & 75 \\
\hline Euxaoctopus pillsburyae & 24 \\
\hline Octopus (Octopus) vulgaris & 300 \\
\hline Octopus (Octopus) briareus & 120 \\
\hline Octopus (Octopus) burryi & 70 \\
\hline Octopus (Octopus) carolinensis & 200 \\
\hline Octopus (Octopus) defilippi & 55 \\
\hline Octopus (Octopus) filosus & 72 \\
\hline Octopus (Octopus) joubini & 45 \\
\hline Octopus (Octopus) lobensis & 37 \\
\hline Octopus (Octopus) macropus & 155 \\
\hline Octopus (Octopus) maya & 119 \\
\hline Octopus (Octopus) mercatoris & 20 \\
\hline Octopus (Octopus) tehuelchus & 105 \\
\hline Octopus (Octopus) verrucosus & 80 \\
\hline Octopus (Octopus) zonatus & 30 \\
\hline Pteroctopus tetracirrhus & 130 \\
\hline Pteroctopus schmidti & 57 \\
\hline Scaeurgus unicirrhus & 90 \\
\hline Eledone massyae & 75 \\
\hline \multicolumn{2}{|c|}{$\begin{array}{l}\text { Species not included (no available information): Rossia } \\
\text { moelleri, Rossia brachyura, Rossia bullisi, Semirossia } \\
\text { patagonica, Pickfordiateuthis pulchella, Octopus (Octo- } \\
\text { pus) alecto, Octopus (Octopus) pentherinus, Octopus } \\
\text { (Octopus) sanctaehelenae, Eledone gaucha, Vosseledone } \\
\text { charrua }\end{array}$} \\
\hline
\end{tabular}

Table A2. Cephalopod sizes in the eastern Atlantic

\begin{tabular}{|c|c|}
\hline Species & $\begin{array}{l}\text { Maximum mantle } \\
\text { length }(\mathrm{mm})\end{array}$ \\
\hline Sepia (Sepia) officinalis & 490 \\
\hline Sepia (Sepia) bertheloti & 175 \\
\hline Sepia (Sepia) elobyana & 53 \\
\hline Sepia (Sepia) hierredda & 500 \\
\hline Sepia (Sepia) insignis & 60 \\
\hline Sepia (Sepia) papillata & 140 \\
\hline Sepia (Sepia) tuberculata & 82 \\
\hline Sepia (Sepia) vermiculata & 287 \\
\hline Sepia (Anomalosepia) australis & 85 \\
\hline Sepia (Hemisepius) typica & 26 \\
\hline Sepia (Hemisepius) pulchra & 22 \\
\hline Sepia (Rhombosepion) elegans & 89 \\
\hline Sepia (Rhombosepion) orbignyana & 120 \\
\hline Sepiella ornata & 100 \\
\hline Sepiola rondeleti & 60 \\
\hline Sepiola affinis & 25 \\
\hline Sepiola atlantica & 21 \\
\hline Sepiola aurantiaca & 20 \\
\hline Sepiola intermedia & 28 \\
\hline Sepiola knudseni & 18 \\
\hline Sepiola ligulata & 25 \\
\hline Sepiola robusta & 28 \\
\hline Sepiola steenstrupiana & 30 \\
\hline Sepiola pfefferi & 13 \\
\hline Rondeletiola minor & 23 \\
\hline Sepietta obscura & 30 \\
\hline Sepietta oweniana & 40 \\
\hline Sepietta neglecta & 33 \\
\hline Rossia macrossoma & 60 \\
\hline Rossia palpebrosa & 45 \\
\hline Neorossia caroli & 83 \\
\hline Loligo (Loligo) vulgaris vulgaris & 420 \\
\hline Loligo (Loligo) vulgaris reynaudi & 400 \\
\hline Loligo (Alloteuthis) media & 120 \\
\hline Loligo (Alloteuthis) subulata & 200 \\
\hline Loligo (Alloteuthis) africana & 190 \\
\hline Loligo forbesii & 900 \\
\hline Lolliguncula (Lolliguncula) mercatoris & 50 \\
\hline Illex coindetti & 370 \\
\hline Todarodes sagittatus & 750 \\
\hline Todarodes angolensis & 350 \\
\hline Todaropsis eblanae & 270 \\
\hline Octopus (Octopus) vulgaris & 300 \\
\hline Octopus (Octopus) burryi & 70 \\
\hline Octopus (Octopus) defilippi & 55 \\
\hline Octopus (Octopus) macropus & 155 \\
\hline Octopus (Octopus) salutii & 130 \\
\hline Pteroctopus tetracirrhus & 130 \\
\hline Scaeurgus unicirrhus & 90 \\
\hline Eledone cirrhosa & 155 \\
\hline Eledone moschata & 188 \\
\hline \multicolumn{2}{|c|}{$\begin{array}{l}\text { Species not included (no available information): Sepia } \\
\text { (Sepia) angulata, Sepia (Hemisepius) dubia, Sepia } \\
\text { (Hemisepius) robsoni, Sepia (Rhombosepion) hieronis, } \\
\text { Inioteuthis capensis, Aphrodoctopus schultzei, Enter- } \\
\text { octopus magnificus, Octopus (Octopus) sanctaehelenae, } \\
\text { Eledone nigra, Eledone thysanophora }\end{array}$} \\
\hline
\end{tabular}

